\title{
Malta and Lanzarote (Canary Islands, Spain) Cart-ruts and Rock Prehistoric Calendar at Zonzamas, Lanzarote -"Quesera"/Cheeseboard-
}

\author{
Antonio Arnaiz-Villena*, Marcial Medina, Jose Palacio-Gruber, \\ Adrián Lopez-Nares and Valentín Ruiz-del-Valle \\ Department of Inmunology, University Complutense, School of Medicine, 28040 \\ Madrid, Spain \\ ${ }^{*}$ Corresponding Author: Antonio Arnaiz-Villena. Departamento de Inmunology, Facultad de Medicina, Universidad \\ Complutense, Pabellón 5, planta 4. Avd. Complutense s/n, 28040, Spain. \\ E-mail:arnaizantonio@gmail.com; aarnaiz@med.ucm.es; Web page: http://chopo.pntic.mec.es/biolmol
}

(Received 20 July 2018; Accepted 25 August 2018; Published 5 September 2018)

\begin{abstract}
It is noticed that the abundant Malta cart-ruts fabrication by different cut shape in rocks is similar to "Quesera"/Cheeseboard Lanzarote rock prehistoric lunisolar calendar building. Even more, some Malta cart-ruts associated structures are similar to this Lanzarote rock calendar. Cart-ruts are hand made artifacts that in Malta started to be built up at Bronze Age; at present, they may be found throughout all Mediterranean area (North and South) and also in Atlantic islands, including Lanzarote, as described in this paper, British Islands and Azores. Rock calendar-like structures in Malta are associated to cart-ruts; we have analyzed those at San Gwan, Ta Cenc and San Pawl tatTarga. It is uncertain whether they might have been used as calendars. Cart-rut purposes have been debated. Some of them may be associated to water collection, but their use to bear vehicles is not credible for many of them are constructed on steep hills, or even top of mountains, and with no sign of vehicles or living beings close to them. We put forward an astronomical /religious purpose for some of them to measure time and directions (space), like most Malta temples do have, i.e.: main door oriented to South, Summer Solstice marking and a Sun calendar throughout 12 months starting June 21 st (Mnajdra and Hagar Qim temples). Search of a universal purpose for all extant cart-ruts in all areas, which are time stratified, is not a right approach for us.
\end{abstract}

Keywords: Malta, Cart-ruts, Lanzarote, Quesera/Cheeseboard, Lunisolar calendar, Iberian writing, Guanche writing, Zonzamas, Canary Islands, Guanches, Majos, Archaeoastronomy. 


\section{Introduction}

An enigmatic rock carved artifact had been found al Zonzamas site in Lanzarote Island (Canary Islands, Spain) (Fig. 1) that was named "Quesera"/Cheeseboard (Serra Rafols, 1942). It consisted of carved strips and hollows in rock and has been described by us as the lunisolar ancient prehistoric Canarian Calendar that was used by ancient Canarians (Guanches, Majos in Lanzarote), as referenced in all available documents (Anónimo Cedeño, 1682; Marin de Cubas, 1642; Barrios García, 2004) (Fig. 2). Canary Islands are placed in Atlantic Ocean in front of African Moroccan Coast and Lanzarote Is. is only $125 \mathrm{Km}$ (78 miles) apart from Africa Coast. Other "Queseras" / Cheeseboards have been described and two of these are nowadays preserved in poor conditions (Medina \& Arnaiz-Villena, 2018a).

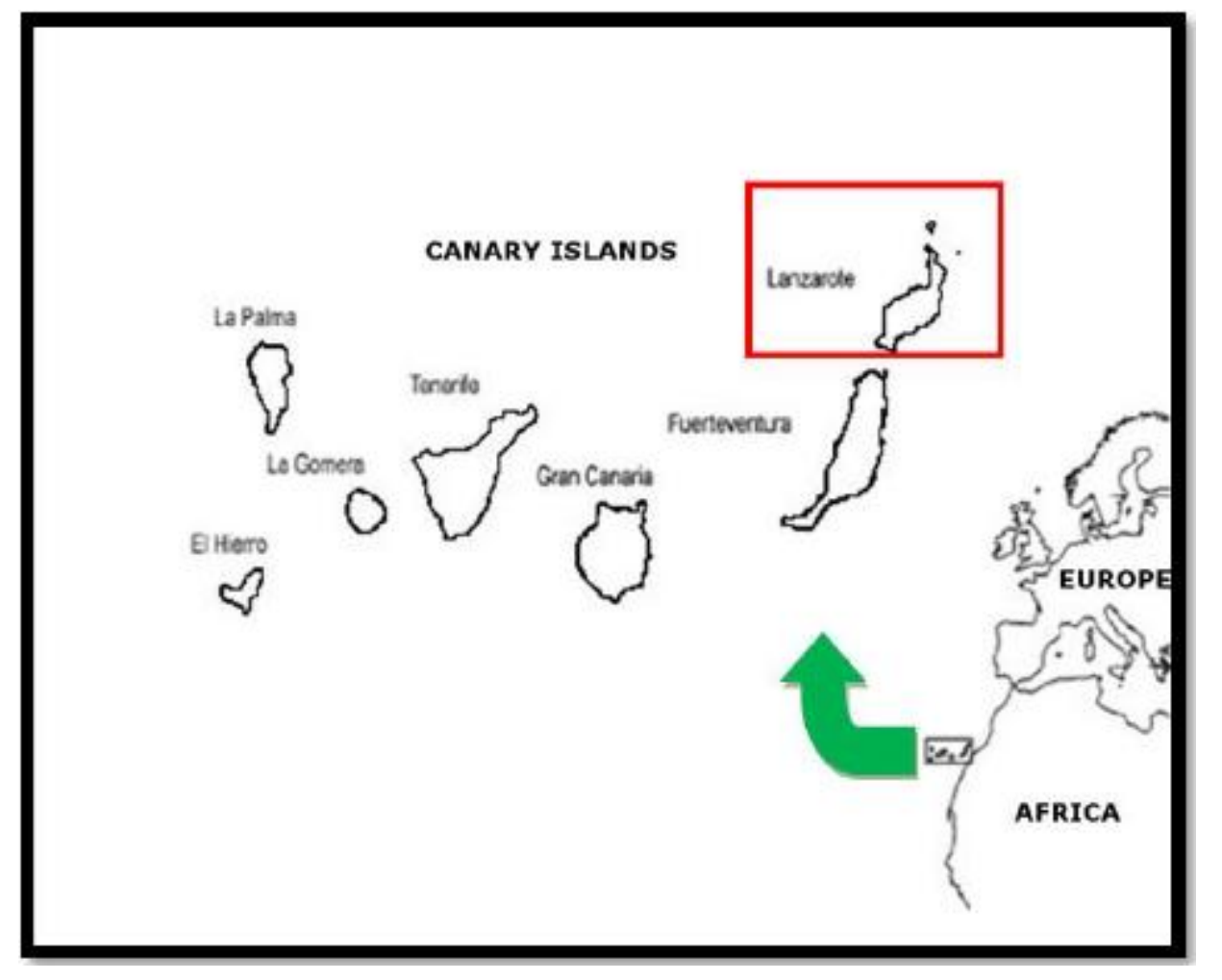

Fig. 1 Map of Canary Islands with islands names and the Atlantic coast lines of Europe and North West Africa.

Lanzarote island is $125 \mathrm{~km}$ (78 miles) apart off African Coast. Interest is on a prehistoric monument at Lanzarote (marked inside a red square): "Quesera"/Cheeseboard lunisolar prehistoric rock calendar at Zonzamas site. 


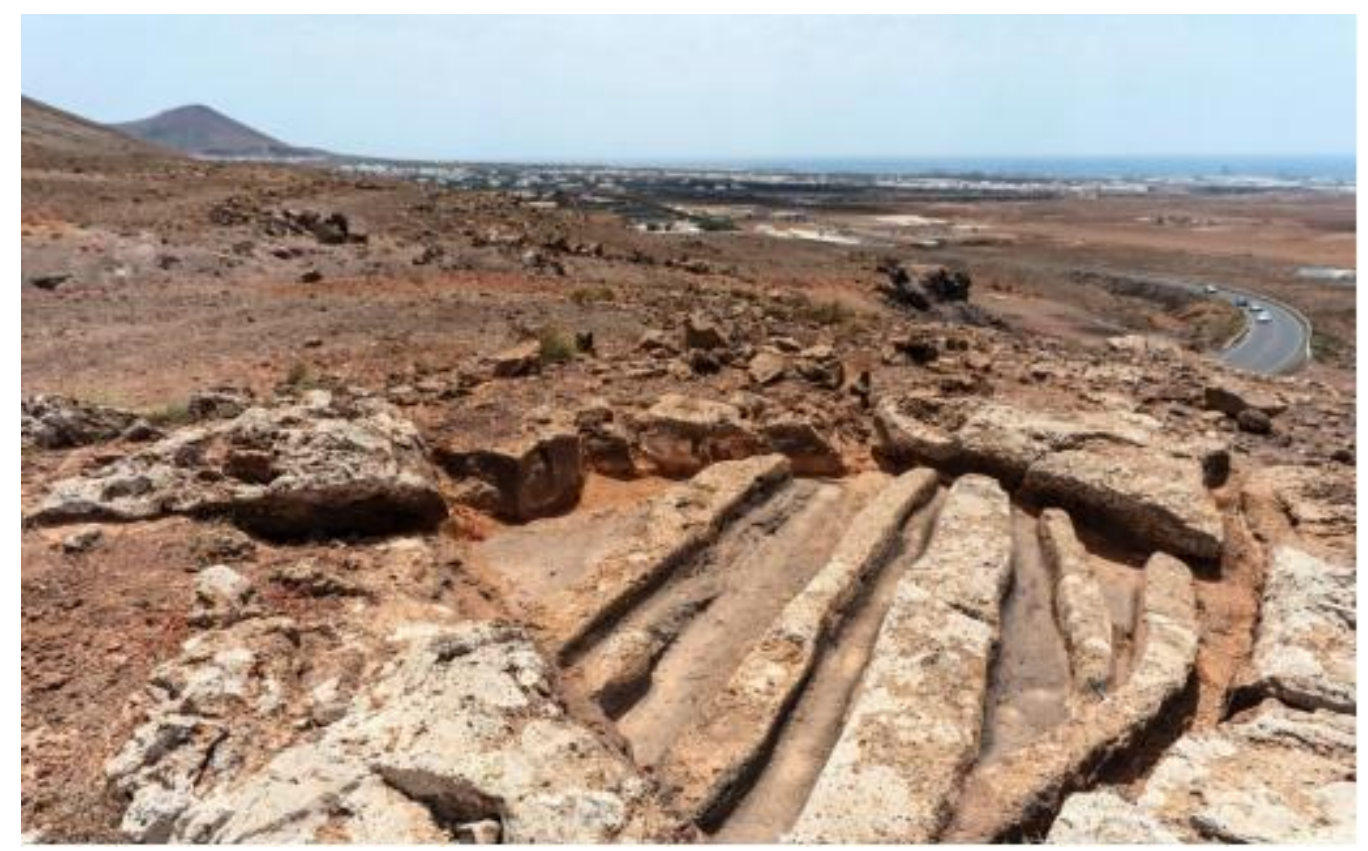

Fig. 2 "Quesera" (Cheeseboard) of Zonzamas, Lanzarote

(29. 0005702 $2^{\circ}$ North latitude and 13. $5677934^{\circ}$ West longitude).It consists of six grooves carved in basaltic rock, $30 \mathrm{~cm}$ high (11.8 inches) and between 27- $45 \mathrm{~cm}$ wide (10.6 - 17.7 inches). Its largest diameter is 3.9 meters (127.9 feet) six/rock segments-strips were left prominent between carved channels. Podomorph rock engravings are recorded in other nearby places (Cabrera Perez, 1992). Its location lays on a hill close to ancient capital, Zonzamas; it has a wide view to present day Lanzarote capital, Arrecife.

Rock carved strips and hollows from this Lanzarote lunisolar calendar were found apparently very similar in manufacture to many Malta cart-ruts which have been puzzling archaeologists and other scholars in dating and purposes, once Nature has been discarded by most authors as their origin in Malta Archipelago (Fig. 4) and in other countries cart-ruts. Malta megalithic temples building started about 5th millennium BC (Copper Age) and cart-ruts started to be built in Bronze Age (2,500-800 BC) (Trump, 2002; Trump, 2008; Bonnici, 2007; this last reference comprises results which are gathered in a multi-author volume of a Culture 2000 Program project financed by European Union). 


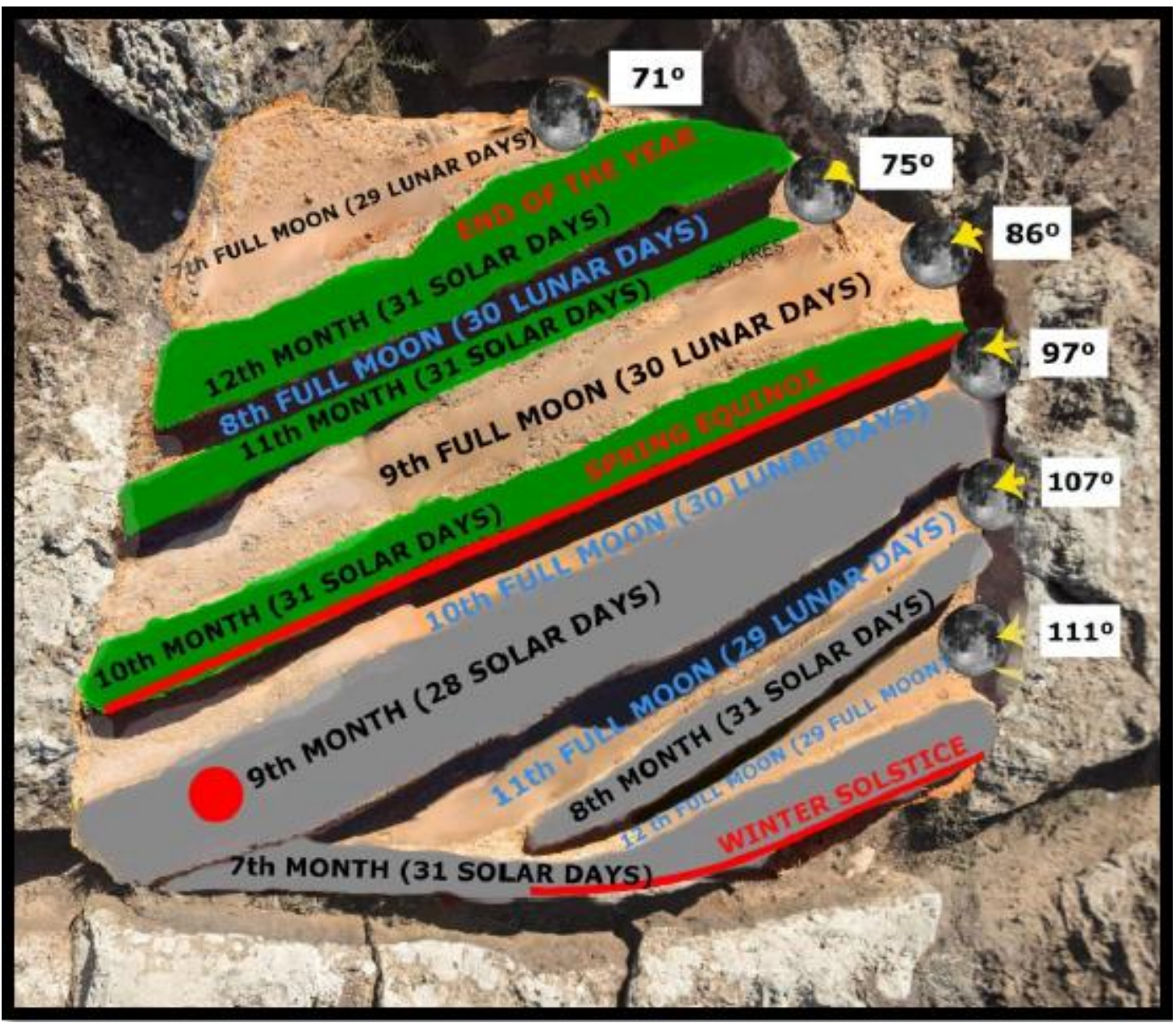

Fig. 3 Lunisolar "Quesera"/Cheeseboard Prehistoric Canarian Calendar (Second half year time) (Medina and Arnaiz-Villena, 2018b)

Sun Calendar: was studied by Medina and Arnaiz-Villena (2018a). Second half of year is represented in this figure; the solar month was shown in the first bottom prominent strip and following sun months were shown in the following upwards prominent rock strips. Sunrises and Sunsets azimuths for solstices and equinoxes are given in Fig. 6 of Ref. Medina and Arnaiz-Villena, 2018a, a previous paper analyzing only Sun calendar. Note that Sunsets azimuths for Equinoxes are at $271^{\circ}$ in Fig. 6 of paper by Medina and Arnaiz-Villena (2018a) and there is mistake in this reference, as it is stated "Azimuth Sunrise" instead of "Azimuth Sunset".

Lunar Calendar: The lunar month is represented in first top hollow carved strip at $71^{\circ}$ moonrise azimuth January 7th 2015; following lunar months are represented in the following bottom wards hollow/carved strips. Starting lunar month azimuths are depicted in white squares in Medina and Arnaiz-Villena, 2018b, in this reference Table 1 and Appendix 1 for consulting first lunar months day and sunrise azimuth and moonset (Anónimo Cedeño, 1682; Marín de Cubas, 1687; Barrios García, 2004). 


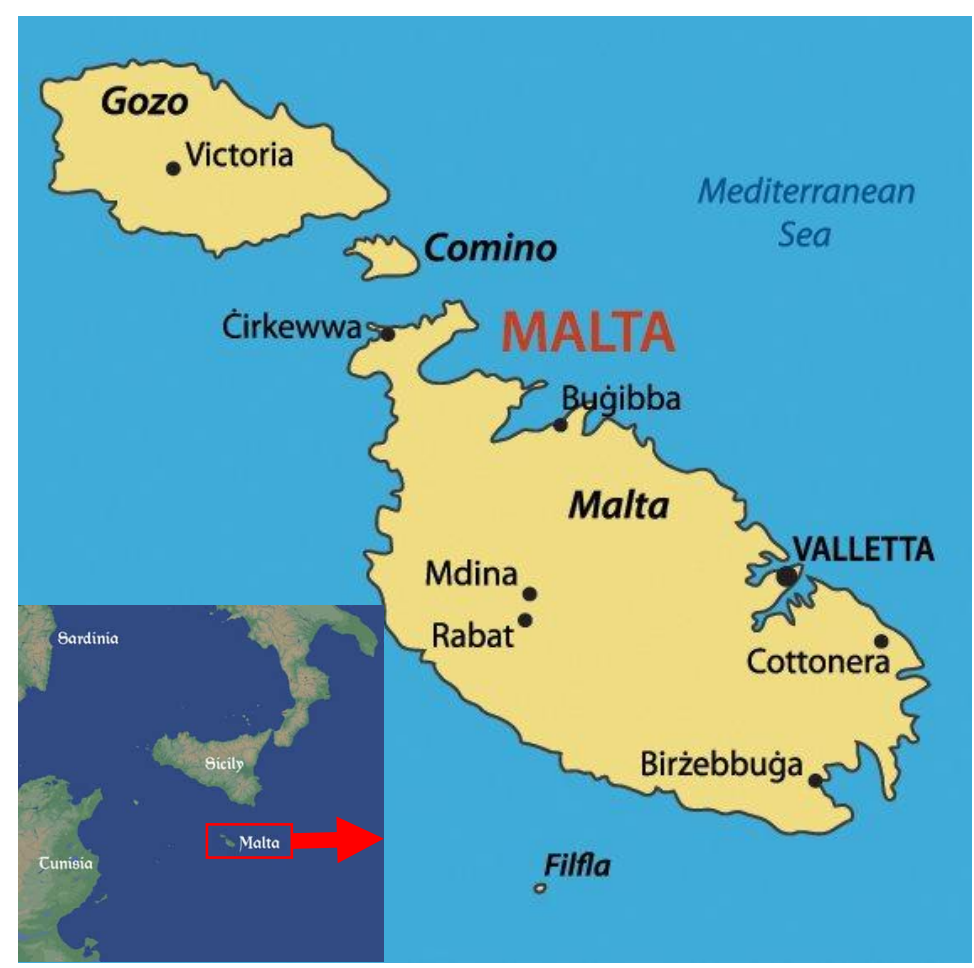

Fig. 4 Malta Archipelago

It has been linked to Sicily during the Last Glaciation. It is $95 \mathrm{Km}$ (59 miles) far from Sicily (Italy), 320 Km (198 miles) far from Libyan Coast and $300 \mathrm{Km}$ (186 miles) far from Tunisia Coast.

In view of construction similarities of cart-ruts and "Quesera"/Cheeseboard Calendar found in Lanzarote (Medina and Arnaiz-Villena 2018a), i.e.: carved rock strips with alternating hollows and prominences, a wide review of Malta cart-ruts (see, Fig. 5) construction placement was carried out by consulting web pages: The Megalithic Portal (http://www.megalithic.co.uk/; Heritage Malta http://heritagemalta.org/tag/cart-ruts/; Cart-ruts Malta http://www.cartrutsmalta.com/) and by visiting to Maltese Archipelago to inspect specific sites and the abundant cart-ruts over Malta and Gozo Islands by one of the authors (A A-V). 


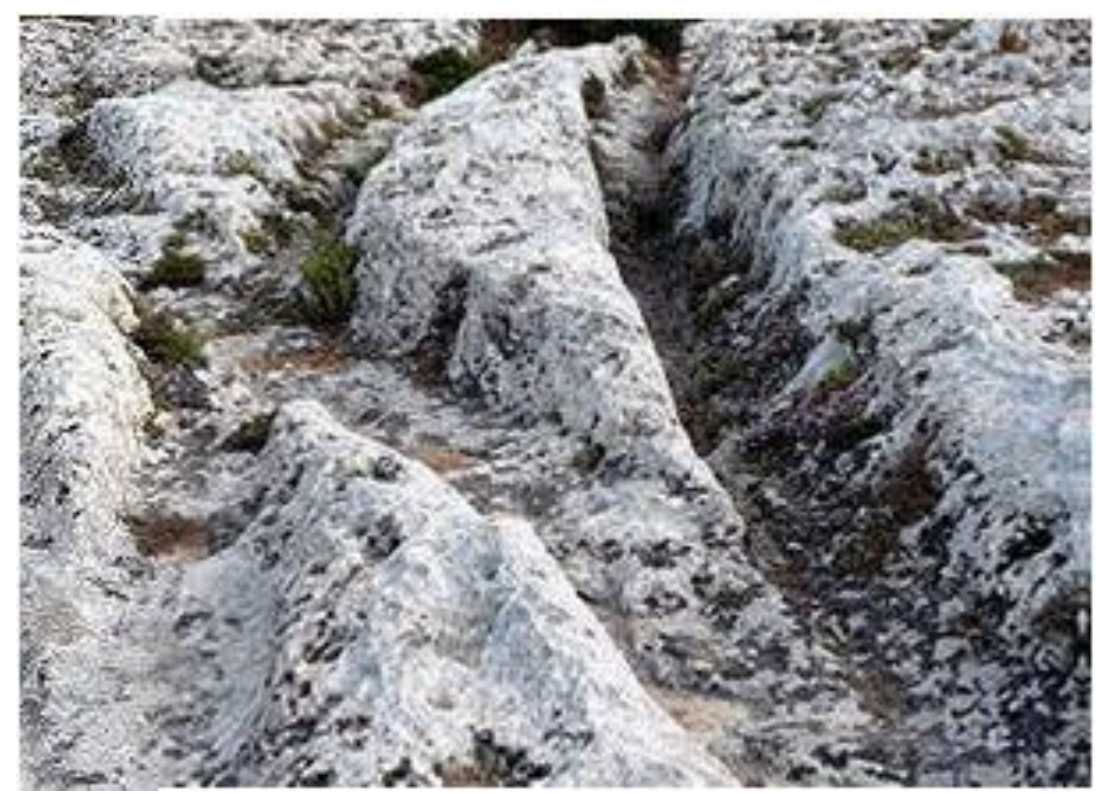

Fig. 5 Cart-Ruts: Clapham Junction, Malta Island South Coast $35.852458^{\circ} \mathrm{N} 14.396883^{\circ} \mathrm{E}$ http://www.cartrutsmalta.com/

\section{Materials and Methods}

\section{Malta}

Malta field work was carried out with a compass/ inclinometer NS1620 (SAC Electronics, Sutton, Nottingham Shire, UK). At least three different measurements were taken for each value. Also, a Sony Camera Cybershot 14.1 Megapixels Carl-Zeiss lens Vario-Tessar was used for photograph work. In addition, Android software Ulysse Gizmo was also employed as compass/inclinometer to obtain azimuth, geographical directions and longitude/latitude. Its software was calibrated each time after one single use and several measures were taken in three different times; also reverse direction measurements were taken for assessing data. Values obtained by SAC compass/inclinometer were coincidental with those obtained by Ulysse Gizmo software in a Sony Xperia G3112 cellular phone. Web-pages of Malta and World cart-ruts photographs were searched as referenced in text and in References Section. 


\section{Lanzarote}

\section{Study}

One of the authors, Marcial Medina was born in Lanzarote. He is a freelance archaeologist who has searched every Lanzarote's corner and has discovered many ancient rock engravings and other ceramic and archaeological tools. He is a sailor and had knowledge of astronomic measurements. Thus, he measured sunrise azimuth and altitude every day during a two years period (2014-2015) from the "Quesera" de Zorzamas elevation (162 meters, 531 feet above sea level) placed at $29.0005702^{\circ}$ North latitude and $1.5677934^{\circ}$ West longitude (Medina and Arnaiz-Villena, 2018a). He has also found and recorded many archaeological rock engravings and other artifacts, like cart-ruts in Lanzarote.

\section{Methods}

SPSMAP 60c color map Navigator was used for local coordinate assessment (Garmin International, Kansas, and USA). Suunto Tandem/360PC/360R DG compass and inclinometer (Turku, Finland) was used to astronomical records (Medina and Arnaiz-Villena, 2018a) and a computer program calculated other parameters (SunEarthTools.com, online program). Other instruments were used for reassessing measurements: above mentioned SPSMAP navigator and binoculars 7x50 Estancos Anti-Impactos with Plastimo Compass (Sea Binoculars, Plastino USA Inc, Wilmington, Delaware, USA).

\section{Results}

\section{Malta}

Several cart-ruts sites in Malta could have apparent similarities with Lanzarote "Quesera" / Cheeseboard which need further study. We decided to study three of them. One of the cart-ruts sites was placed at San Gwan city center (Fig. 6a, 6b and 6c) surrounded by modern buildings which had obviously destroyed a great part of cart-ruts. In fact, removing bushes and grasses it was possible to distinguish 6 rock carved channels and 6 strips. Our construction view may not correspond to the initial builder aim, however, twelve rock elements (prominent and hollow strips), like in Lanzarote "Quesera"/Cheeseboard were recorded (Fig. 6); this bunch of cart-ruts is deteriorated and also some of the strips go further up (about 30 meters - 98 feet) as far as they 
became discontinuous, probably because of construction of modern houses and destruction.
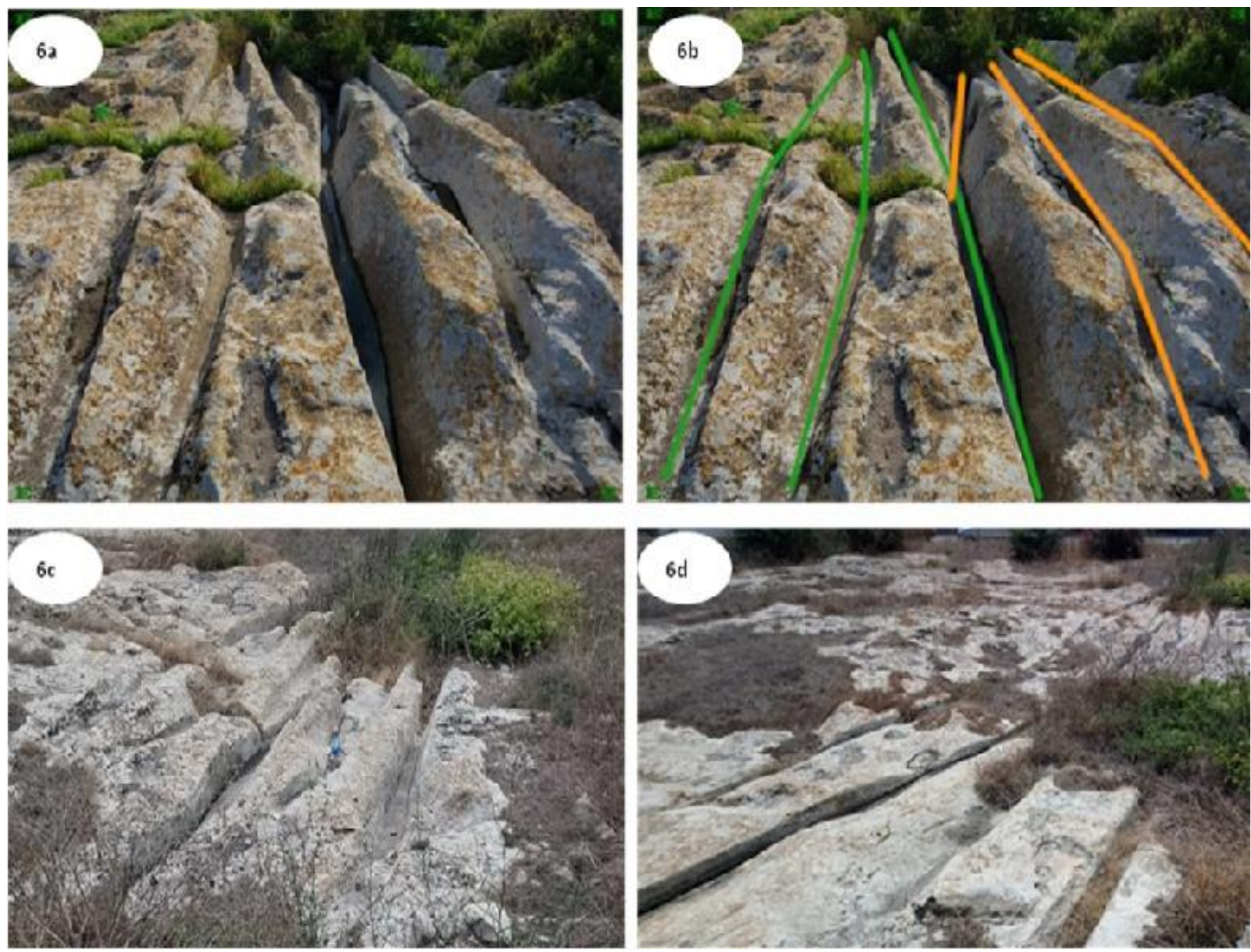

Fig.6 Archaeological site of Tal-Mensija, San Gwann village, (Malta).

35.911 $\mathrm{N}, 14.478^{\circ}$ E. http://www.cartrutsmalta.com/ - 6a - Plain photograph. $6 b$ - Underlined carved strips in order to make it clear that it is a construction similar to Lanzarote "Quesera" / Cheeseboard rock prehistory calendar. $6 c-A$ North-East photograph of the cart-rut complex because ruts follow a

South-West direction. $6 d-A$ close up photograph of $6 c$. The two photographs were taken on summer noon day with full sun light which fades colours and also plants and dried bushes are exuberant because of the time of the year Fig.6. Archaeological site of Tal-Mensija, San Gwann village, Malta). 35.91 ${ }^{\circ} \mathrm{N}$, 

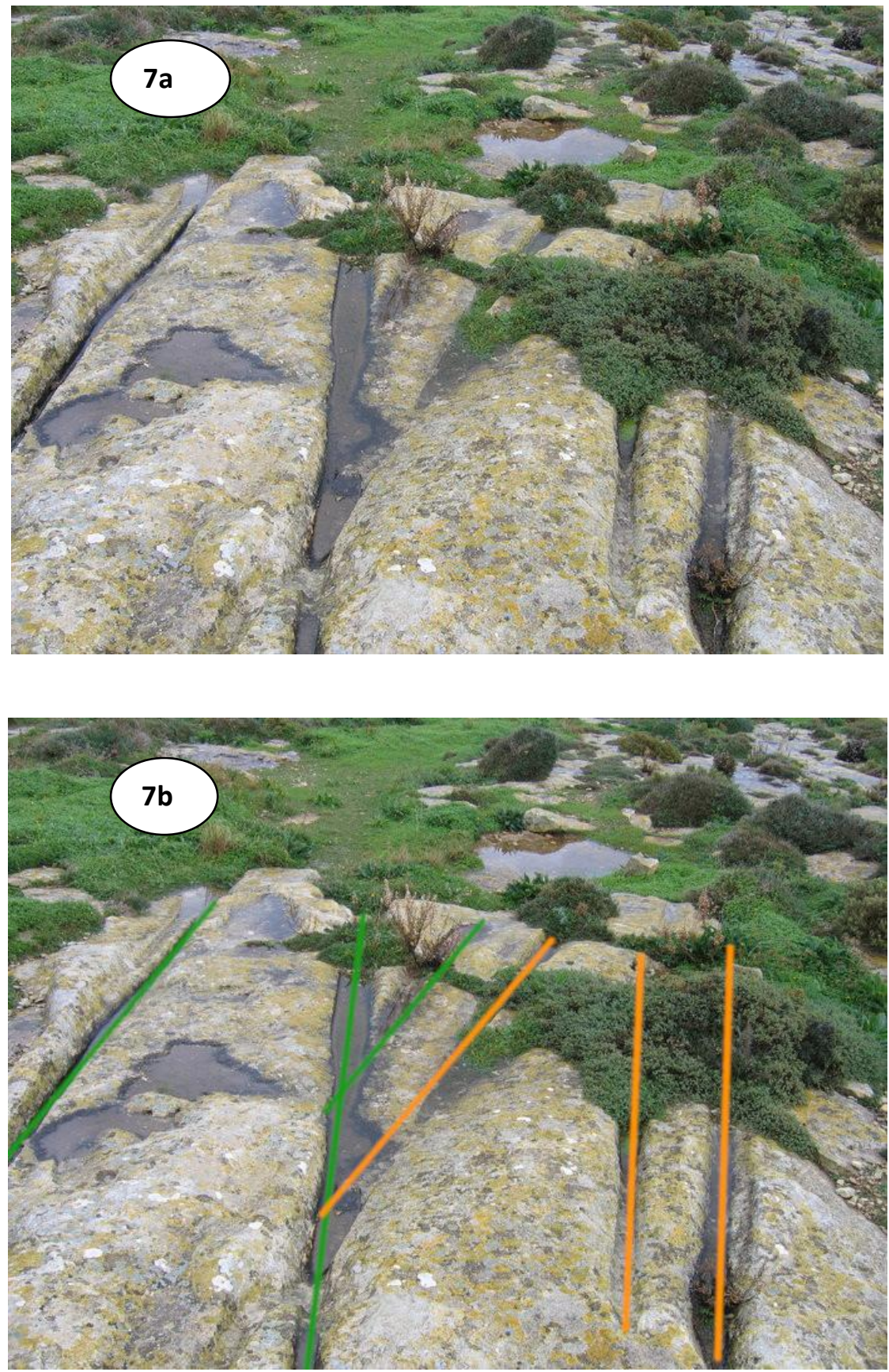

Fig.7 Archaeological site of Ta Cenc, Sannat town, close to clifts (Gozo Island, Malta). $36.017^{\circ} \mathrm{N}, 14.259^{\circ} \mathrm{E}-7 \mathrm{a}$ - Plain photograph. $7 b$ - Underlined carved strips in order to make it clear that it is a construction similar to Lanzarote "Quesera" / Cheeseboard rock prehistory calendar 
The second cart-rut site was placed at Ta Cenc site on the southern part of Gozo Is. close to clifts (Fig. 7) and to the city of Sannat. Again, a structure similar to "Quesera"/Cheeseboard was observed in this case (Fig. 7a and 7b) and 6 hollows and 6 prominent strips could be traced; this figure is also similar to the lunisolar prehistoric calendar found in Lanzarote ("Quesera"/Cheeseboard). This structure that was more isolated than the first one studied at San Gwan city center (Fig. 6).

In addition to these two sites, a third cart-rut site was studied at San Pawl tatTarga because it also had a convergent stem of cart-ruts that had been cut because a modern road has been built (from Salina town to Naxxar town), see aerial photograph of part of the complex in Fig.8. The cart-rut stem is of a doubtful interpretation; it might be a "Quesera"/Cheeseboard construction or not, because it is mostly destroyed and covered by dried bushes at present.

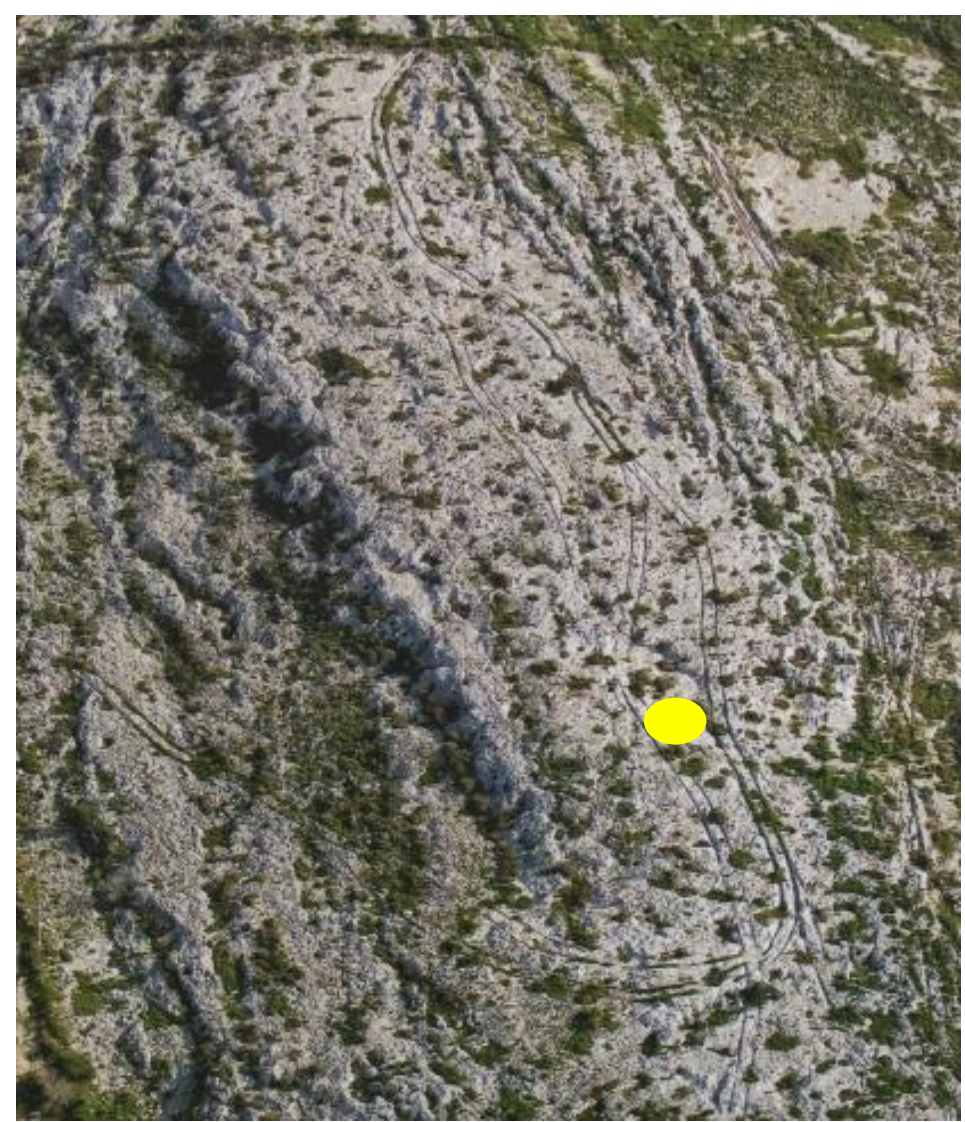

Fig. 8 Aerial view of San Pawl tat-Targa cart-ruts complex.

Yellow dot: place where a apparent site to collect water in a big cistern is found cut into rock. Probably it was a prehistoric water tank, like others already found and related to Malta temples (see Fig. 9k). 

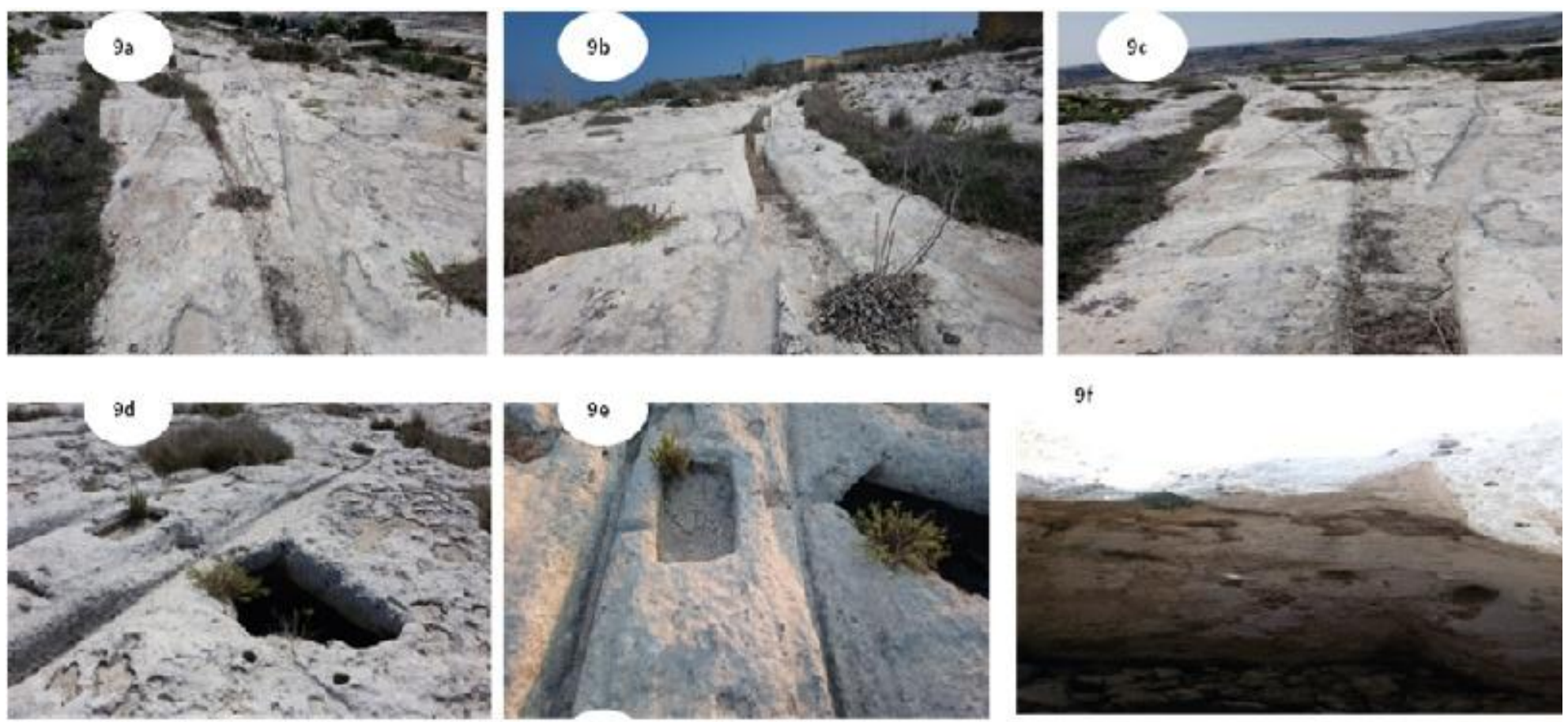

9h

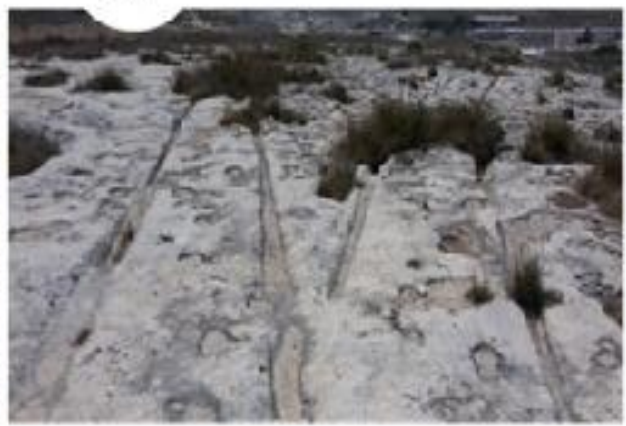

$9+$

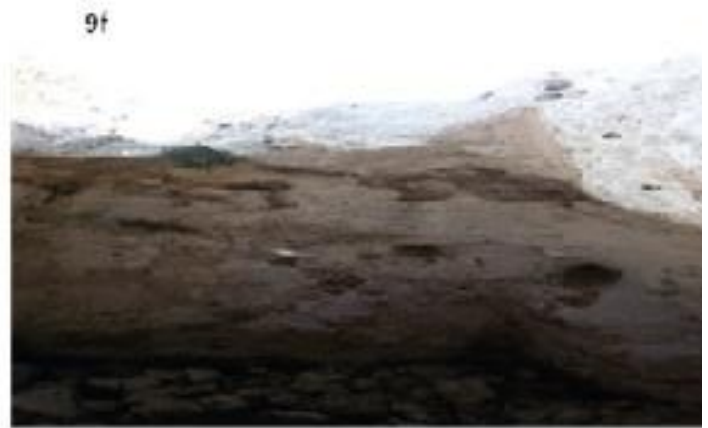

$9 k$

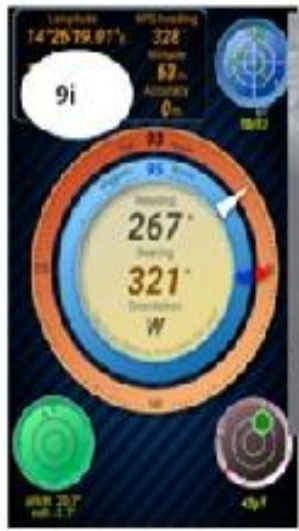

9

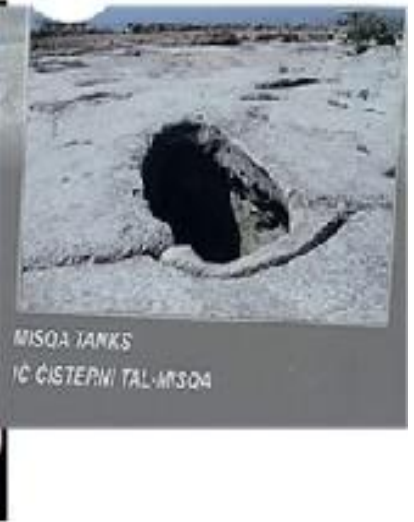

Fig. 9 San Pawl tat-Targa cart-ruts complex and water cistern.

$9 a$ - Convergent stem of cart-rut. Eastern side of road from Salina to Naxxar. A similar

"Quesera"/Cheeseboard structure could appear if all place was cleaned off bushes and plants.9b - Cart-ruts stemming from $9 a$ downhill.9c - A close up down of 9b. 9d-Some meters down the same cart-rut rectangle cut in the rock. In the right hand side is a small cut piece that goes through the cart-rut itself towards cistern entrance. $9 e-A$ close up picture of $9 d$. A square has been cut in the cart-rut rock, where a transversal to the rock dent has also been built for directing water to cistern $9 f$-Cistern walls showing how worked very well. $9 \mathrm{~g}$ - Same cart-rut about 50 meters ( 164 feet) down cistern entrance showing how it is crossed by another cartrut.9h-A close up photograph of $9 g .9 i-$ Coordinates and this particular cart-rut group direction, azimuth or bearing, and other plade geographical data are depicted by Ulysse Gizmo compass/inclinometer software program. Cart-ruts maind direction is almost exactly East to West downhill, for that coordinates, as depicted. This suggests that cart-ruts follow direction of Equinoxes Sun arch (Spring and Autumn starting) $9 k$ - Cistern entrance of one of the several water tanks which are supposed to have given water to both Mnajdra Temples and Hagar Qim Temples (3,000-2,500 years BC). 
However, this site was particularly interesting because in the middle of the tridimensional inclined plain (about more than $40^{\circ}$ inclination angles), there is a big water ancient cistern entrance and a channel that cuts a cart-rut for facilitating water flow into the cistern (Fig. 9d,e,f); it was done for diverting water directly into big cistern (Fig. 9). This may indicate a function for some of the cart-ruts, consisting of picking up water. This has already been suggested and discarded by most authors (Trump, 2002; Trump, 2008; Bonnici, 2007) because these cistern structures have not been found in most cart-ruts places. Notwithstanding, they might be found if looking for them.

\section{Lanzarote}

Cart-ruts have also been found in several locations at Lanzarote Island. One of the cart-ruts complex has been observed in Tenezera or Tenesera Mountain, one of the highest volcanic mountains in Lanzarote (Fig. 10). In the same Tenezera Mountain, Lybic Berber and "Latin" or Ibero-Guanche (Arnaiz-Villena \& Alonso-Garcia, 2001; https://commons.wikimedia.org/wiki/File:Iberian-Guanche_inscriptions.pdf) rock inscriptions have been found.

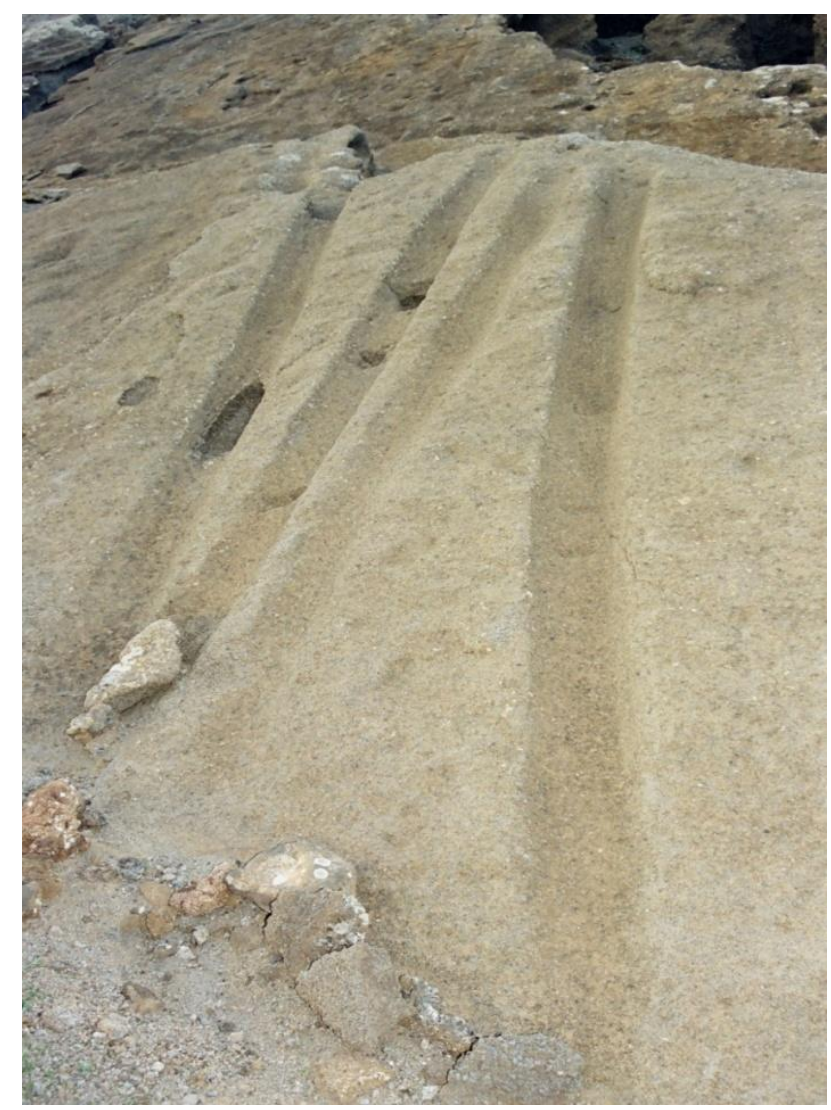

Fig.10 Cart-ruts. Tenezera Mountain, Tinajo town area (Lanzarote, Canary Islands) 


\section{Discussion}

Lanzarote "Quesera"/Cheeseboard calendar and Malta Cart-Ruts.

Three different constructions have been found by us in Malta that have similarities with "Quesera"/Cheeseboard Lanzarote rock prehistoric calendar: in San Gwan (Fig. 6a, 6b and 6c), Ta Cenc clifts (Gozo Is., Fig. 7a and 7b) and San Pawl tat-Targa (Fig.8 and Fig. 9). Whether they have been used as calendars, as put forward for Lanzarote "Quesera"/Cheeseboard is not certain. In fact, they are not isolated artifacts, like the Lanzarote one and they seem to be a part of cart-ruts complexes.

Cart-ruts are nowadays seen wide-spread throughout Malta and Gozo Islands. There are extensive studies of many of the sites which are nowadays identified and some of them widely studied (Trump, 2002; Trump, 2008; Bonnici, 2017). They have been constructed by man and not by Nature because of their intentional, swerving and steps and also their sometimes strict parallelism, convergence or curve perfection in many cases (Trump, 2008). They started to be built at Malta around Bronze Age or before at Temples age (Trump, 2002; Trump, 2008; Bonnici, 2007) and they may have been continued to be built in later periods (Trump, 2002; Trump, 2008; Bonnici, 2007). Their function is debated: most of them are useless as rail roads for any kind of transport; therefore, this "cart-ruts" name is misleading. At present, scholars only think in practical and present day terms of use. However, the problem of the many cart-ruts use and purpose in Malta is not more important than the problem of explaining why so many megalithic temples were built in Malta since 5th millennium BC, many of them with precise astronomical intentionality. By homology with temples, one could not discard that cart-ruts are also necessary for establishing time and also astronomical/geographical directions or even for a religious use.

It is widely accepted that both Malta megalithic temples and cart-ruts belong to Megalithic Culture (Trump, 2002; Trump, 2008; Bonnici, 2007; Bonanno, 2017) and that some of them may have been built in more recent times. Putative vehicles that might have been used to cart-ruts driving according to some authors, should be sciencefiction ones, able to be driven up and downhill on high angular slopes: see cart-ruts at San Pawl tat-Targa (Fig. 9). Also, they do not take into account isolated cart-ruts in Atlantic islands, Mediterranean area or Malta. 
In addition, cart-ruts may have had multiple uses in the same or in different places. Our own studies at San Pawl tat-Targa (Fig. 9) suggest that a part of the complex could have been used to collect and store water. Some other cart-ruts could have also used for that purpose. In fact, cisterns to feed Mnajdra Temples and Hagar Qim Temples have been found (Fig. 9). Postulating a homogeneous and universal use for all known cart-ruts may not be a correct approach for Atlantic,Mediterranean and Malta ones.

\section{Lanzarote cart-ruts and "Quesera"/Cheeseboard calendar}

Some isolated cart-ruts have been found in Lanzarote in different places (authors own observations). A photograph of one of the complex placed at Mountain Tenezera (Tinajo town area) is shown in Fig. 10. This site also contains rock graffiti written in Berber-Lybian writing and also in more ancient "Latin" Ibero-Guanche scripts. The latter are written in Iberian alphabet; many other Iberian rock scripts are spread by Lanzarote and Fuerteventura Islands, and also found in El Hierro (Canary Islands) (Arnaiz-Villena $\&$

Alonso-Garcia, 2001; https://commons.wikimedia.org/wiki/File:Iberian-Guanche inscriptions.pdf; ArnaizVillena et al., 2015; Medina \& Arnaiz-Villena, 2018b).

"Quesera"/Cheeseboard prehistoric calendar type of building by man is similar to rock carved cart-ruts with their different shapes (angular, squared, rounded, and mixed) (Bonnici, 2007). No Roman or Phoenician construction has been documented similar to "Quesera"/Cheeseboard or cart-ruts. Since cart-ruts are dated in Malta at Bronze Age, we could put forward that "Quesera"/Cheeseboard Lanzarote Calendar belongs also to Bronze Age Culture and peoples who were living at Canary Islands by then. This has to be further studied with absolute measures, if possible (like $\mathrm{C}^{14}$ or others).

\section{Cart-ruts in other part of the World including Atlantic Islands}

The European Community Research Project led by Bonnici (2009) has widely studied cart-ruts in Mediterranean area. Different authors explain their discoveries and views. There is a general disagreement about use, but to our view the same discussion should exist to explain why there are so many megalithic temples built in Malta, since $5^{\text {th }}$ millennium BC. Even this controversy is not a big problem compared to how a 20 tons 
rectangular stone could be handled and rised, like the one in Mnjandra temple (Malta, 3,000 BC, $6.40 \times 3$ meters, $21 \times 9.8$ feet) and in other Atlantic and Mediterranean megaliths. In fact, tons of stone handling is a bigger problem of scholars that study Magalithism, than cart-ruts purpose. It has not been properly addressed in part due to dogmatism and presuming today way of thinking for prehistoric Man.

In fact, megalithism use and construction in all manifestations: Menhir, Cromlech (Stone Circle), Dolmens, Temples; it is still an enigma for scholars and the main reward that megalithism is giving now to Science is the astronomical data contained in its constructions. For example, most Malta temples entrance and main axis are oriented to South or South-East. One of the Mnjandra temples main door is recording all sunrises during the starting Summer Solstice, following equinoxes and finally Winter Solstice: in other words, it is a solar calendar similar to that of "Quesera"/Cheeseboard in Lanzarote (Bonanno, 2017). One of the Hagar Quim temples also detects Summer Solstice sunrise though a strategically made wall hole.

Cart-ruts have been found in Italy, France, Switzerland, Greece, Portugal, England, North Africa (Egypt, Dougga in Tunisia and Cyrene in Libya), Turkey and Azerbaijan. A multi-author study (Bonnici, 2007) is missing cart-ruts extant in the Atlantic Ocean, i.e.: Lanzarote (present paper) and Azores (Ribeiro et al, 2015; Ribeiro et al, 2017; Rodrigues et al, 2015).

\section{Conclusion}

1. "Quesera"/Cheeseboard prehistoric calendar found in Zonzamas, Lanzarote, has similarities in man building (rock carved strips) with Malta cart-ruts.

2. Some of the Malta cart-ruts convergences might have been used as calendars, although this area needs further studies.

3. Cart-ruts are found all over the Mediterranean and also in Atlantic Islands, like British Isles, Lanzarote (Canary Islands) and Azores. They are specifically abundant all over Malta and Gozo Islands surface, and might have been ever more frequent in the past 
4. The age of first cart-ruts dating is Bronze Age in Malta and this may be extended to other places like Lanzarote where there is not documented or archaeological context indicating that Phoenician or Romans could have constructed its cart-ruts

5. The cart-ruts have been made by man. Their use is debated and may have been used for different purposes, including collecting and keeping water. Otherwise, their use may have more to do with the many megatlithic temples in Malta and in other places that have been built up for religious or astronomic purposes measurement. In other words, cart-ruts may have been used to measure time and space direction (astronomy/geography). Shadows made by hills or sticks on cartruts may have measured Sun and other astronomical parameters.

6. Archeoastronomy which is regarded by many scholars with reluctance is one of the few rewards that study of Megalithism is nowadays given to Science.

\section{Acknowledgements}

We thank University Complutense from Madrid (Spain) for its support and the following colleges who have been important for carrying out present work: Julián Rodríguez Rodríguez, Antonio Jesús Montelongo Franquiz, María Antonia Perera Betancor, Máximino Álvarez Pérez, José Manuel Espinel Cejas, Ramón Alfonso Hernández and Orlando Batista Aparicio. Marianne Van der Sluys and Jesús Gonzalez Artabe were (and are) also important for spreading light in Lanzarote archaeology and their help is indebted.

Conflicts of Interest: The authors declare no conflict of interest.

\section{References}

Anónimo Cedeño. (Antonio Cedeño?). 1682. Breve Resumen y Historia Verdadera de la Conquista de Canaria. Compilation and Edition by Barrios Garcia J. (2016-2017)

Arnaiz-Villena A. \& Alonso García J. 2001. Egipcios, Bereberes, Guanches y Vascos. Ed. Visión Libros. (3rd Edition 2011) ACCI. Madrid (Spain). 
Arnaiz-Villena A., Muñiz E., Campos C., Gómez-Casado E., Tomasi S., Martínez Quiles N., Martín-Villa M., Palacio-Gruber J. 2015. Origin of Ancient Canary Islanders (Guanches): presence of Atlantic/Iberian HLA and Y chromosome genes and Ancient Iberian language. Int. J. Mod. Anthrop 8: 67-93.

Arnaiz-Villena A., Carballo A., Juarez I., Muñiz E., Campos C., Tejedor B., MartínVilla M., Palacio-Gruber J. 2017. HLA Genes in Atlantic Celtic populations: Are Celts Iberians? Int. J. Mod. Anthrop 10: 50 - 72.

Barrios García J. 2004. Sistemas de numeración y calendarios de las poblaciones bereberes de Gran Canaria y Tenerife en los siglos XIV-XV. Thesis doctoral. Universidad de La Laguna, Tenerife, Islas Canarias (Spain). http://www.etnomatematica.org/publica/trabajos_doctorado/tenerife.pdf

Bonnano A. 2017. The Archaeology of Malta and Gozo. Heritage Malta Publishing. Ed. Gutenberg Press Ltd, Malta

Bonnici H. (Project Leader) 2007. The significance of Cart-Ruts in Ancient Landscapes. Ed. Midsea Books, Malta

Cabrera Perez JC. 1992. Lanzarote y los Majos. Ed. Litografía Romero. Santa Cruz de Tenerife, Canary Islands (Spain).

http://www.megalithic.co.uk/

http://heritagemalta.org/tag/cart-ruts/

http://www.cartrutsmalta.com/

Marin de Cubas TA. 1642. Historia de las Siete Islas de la Gran Canaria Ed. Principe. Transcripcion de F.Osorio Acevedo.Canarias Clasica. 1993. La Laguna, Tenerife, Islas Canarias (Spain)

Medina M. \& Arnaiz-Villena A. 2018a. A lunisolar prehistoric calendar in Lanzarote Island:"La Quesera"(Cheesboard) from Zonzamas. Int. J. Mod. Anthrop. 21:147-161

Medina M. \& Arnaiz-Villena A. 2018b. The Moon: in Prehistoric Rock Calendar "Quesera" -Cheeseboard- at Lanzarote, Canary Islands, Spain. Int. J. Mod. Anthrop. 2:182-212

Ribeiro N., Joaquinito A., Rodrigues Af., Azevedo M.T. 2015. Achaeology and rock art of Macaronesia: New contributions. IV Encontro de Doutorandos e Post-Douorandos Macao.

Ribeiro N., Joaquinito A., Rodrigues AF., Azevedo MT. 2017. Arqueologia e Arte Rupestre na Macronesia, novos contributos. Techne. 3: 113-124 
Rodrigues AF., Martins NO., Ribeiro N., Joaquinito A. 2015. Early Atlantic Navigation: Pre-Portuguese Presence in the Azores Islands. Archaeological Discovery. 3: 104-113.

Serra Rafols A. 1942. Crónica arqueológica visita de estudio a Lanzarote y Fuerteventura. Revista de Historia Canaria n58: 126-127.

Trump DH. 2002. Malta, prehistory and Temples.Ed. Midsea Books Ltd., Malta.

Trump DH. 2008. Cart-Ruts and their impact on Maltese landscape. Ed. Midsea Books Ltd. Malta

To cite this article:

Antonio Arnaiz-Villena, Marcial Medina, Jose Palacio-Gruber, Adrián Lopez-Nares and Valentín Ruizdel-Valle. 2018. Malta and Lanzarote (Canary Islands, Spain) Cart-ruts and Rock Prehistoric Calendar at Zonzamas, Lanzarote -"Quesera"/Cheeseboard-

International Journal of Modern Anthropology. 2 (11): 214 - 231

DOI: http://dx.doi.org/10.4314/ijma.v2i11.10

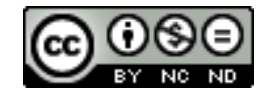

This article, as all articles published in this journal, is under The Creative Commons Attribution: Attribution-NonCommercial-NoDerivatives 4.0 International (CC BY-NC-ND 4.0).

https://creativecommons.org/licenses/by-nc-nd/4.0/ 